\title{
Konsumsi tinggi lauk hewani, rendah sayur dan rendah aktivitas fisik berhubungan dengan kejadian kelebihan berat badan pada anak sekolah dasar
}

\author{
R.L.N.K. Retno Triandhini ${ }^{1 *}$, Angkit Kinasih ${ }^{2}$, Anik Sriwijayanti ${ }^{1}$
}

\section{ABSTRACT}

Background : Overweight and obesity in children are becoming a global health issue that needs special attention. Overweight currently occur not only in urban areas but also in rural areas. One factor that affects over nutrition is the imbalance between food intake and physical activity.

Objective : The objective of this study is to analysis differences in food pattern and physical activitiy between overweight and normal children.

Methods : This study was used cross sectional design. Samples were 10-12 year olds students from 13 elementary schools in Getasan Subdistrict. Dietary intake were measured by Food Frequency Questionnaire (FFQ) form and physical activity were measured by Physical Activity Questionnaire For Older Children (PAQ-C) form. Data were analyzed by Chi-Square and independent t test.

Results : There are significant correlation between physical activity and the incidence of overweight in children ( $\rho=0,003)$. There are significant differences $(\rho<0,05)$ in carbohydrates, animal protein, plant protein and vegetables intake $(\rho=0,001$, $\rho=0,001, \rho=0,001, \rho=0,001)$ between normal and overweight groups.

Conclusion: There are significant correlation between physical activity and the incidence of overweight in children. There are significant differences in carbohydrates, animal protein, plant protein and vegetables intake between normal and overweght groups.

Keywords : Physical Activity, animal protein, vegetables, Food Pattern, Overweight

\begin{abstract}
ABSTRAK
Latar belakang : Kasus kelebihan berat badan (overweight dan obesitas) pada anak-anak menjadi satu masalah kesehatan global yang perlu mendapatkan perhatian khusus. Kasus kelebihan berat badan saat ini terjadi tidak hanya diperkotaan akan tetapi mulai terjadi juga diperdesaan. Salah satu faktor yang mempengaruhi gizi lebih adalah ketidakseimbangan antara asupan makanan dengan aktivitas fisik.
\end{abstract}

Tujuan : Menganalisis perbedaan pola makan dan aktivitas fisik antara anak kelebihan berat badan dan normal pada anak sekolah dasar di Kecamatan Getasan.

Metode : Penelitian ini menggunakan desain cross sectional. Sampel adalah anak berusia 10-12 tahun di 13 sekolah dasar di Kecamatan Getasan. Pengambilan data karakteristik responden dengan cara wawancara dan memberikan kuesioner (umur, jenis kelamin, berat badan, tinggi badan), konsumsi pangan dengan menggunakan formulir FFQ dan aktivitas fisik menggunakan formulir Physical Activity Questionnaire For Older Children (PAQ-C). Analisis data menggunakan uji ChiSquare dan Independent T test.

Hasil : Uji statistika menunjukkan ada hubungan antara aktivtas fisik dan kejadian kelebihan berat badan ( $\rho=0,003)$. Terdapat perbedaan $(\rho<0,05)$ pada asupan makanan karbohidrat, lauk hewani, lauk nabati, dan sayur $(\rho=0,001, \rho=0,001, \rho=0,001$, $\rho=0,001)$ antara anak denan kelebihan berat badan dan normal. Sedangkan asupan buah dan jajanan tidak menunjukan ada perbedaan yang bermakna.

Simpulan: Ada hubungan aktivitas fisik dengan kejadian kelebihan berat badan. Ada perbedaan asupan makanan karbohidrat, lauk hewani, lauk nabati dan sayur antara anak dengan berat badan lebih dan normal

Kata Kunci : Aktivitas fisik, lauk hewani, sayur, pola makan, kelebihan berat badan

\section{PENDAHULUAN}

Kelebihan berat badan (overweight dan obesitas)

1. Program Studi Ilmu Gizi, Fakultas Kedokteran dan Ilmu Kesehatan, Universitas Kristen Satya Wacana. Jl. Kartini No. 11A, Salatiga, Jawa Tengah, telp: 0298-324861

2. Program Studi Pendidikan Jasmani Kesehatan dan Rekreasi, Fakultas Kedokteran dan Ilmu Kesehatan, Universitas Kristen Satya Wacana. Jl. Kartini No. 11A, Salatiga, Jawa Tengah, telp: 0298-324861

*Korespondensi : e-mail: retno.triandhini@staff.uksw.edu pada anak-anak telah menjadi satu permasalahan kesehatan global yang perlu mendapat perhatian khusus. Prevalensi kasus ini semakin meningkat dari ke tahun bukan hanya di Negara berkembang tetapi juga di Negara yang sedang berkembang termasuk Indonesia. ${ }^{1-3}$ Data Riset Kesehatan Dasar (Riskesdas) Indonesia Tahun 2007, 2010, 2013, menunjukkan adanya peningkatan prevalensi angka kelebihan berat badan pada anak-anak di kisaran usia 5-14 tahun. Angka kegemukan anak usia 6-14 tahun berdasarkan hasil Riskesdas 2007 adalah 9,5\% pada anak laki-laki 
dan $6,4 \%$ pada anak perempuan. Menurut data Riskesdas 2010 angka tersebut meningkat menjadi $10,7 \%$ pada anak laki-laki dan $7,7 \%$ pada anak perempuan (usia 6-12 Tahun). Berdasarkan data Riskesdas selanjutnya Tahun 2013, sebesar 10,8\% anak usia 5-12 tahun gemuk sedangkan 8,8\% tergolong sangat gemuk. ${ }^{4-6}$

Anak yang mengalami kelebihan berat badan memiliki risiko lebih tinggi menderita overweight dan obesitas pada masa dewasanya. ${ }^{7}$ Keadaan ini dapat berdampak serius bagi kondisi kesehatan, karena kelebihan berat badan merupakan salah satu faktor risiko terjadinya berbagai penyakit kronis seperti hipertensi, aterosklerosis dan diabetes mellitus tipe 2. ${ }^{8,9}$ Selain itu, obesitas juga memiliki hubungan yang erat dengan peningkatan morbiditas pada anak-anak dan kematian pada orang dewasa. ${ }^{10,11}$

Faktor penyebab terjadinya kelebihan berat badan pada anak sangat komplek. Selain faktor genetik yang diturunkan orang tua kepada anaknya, perubahan gaya hidup merupakan faktor yang sangat erat kaitannya dengan kejadian kelebihan berat badan. Perubahan gaya hidup yaitu kebiasaan makan yang tidak sehat dan kurangnya akitivitas fisik menyebabkan adanya ketidakseimbangan antara kalori yang dikonsumsi dan kalori yang dikeluarkan sehingga dapat menyebabkan kelebihan berat badan. Pola konsumsi masyarakat Indonesia secara umum menunjukkan adanya kebiasaan makan yang tidak sehat, salah satunya adalah konsumsi sayur dan buah yang masih rendah. Data hasil Riskesdas Tahun 2013 menyatakan bahwa sebesar 93,6\% kelompok usia 10 tahun keatas mengonsumsi lemak lebih banyak dibandingkan rekomendasi dari Permenkes no 30 Tahun 2013. Kebiasaan makan tidak sehat yang dimulai sejak masa anak-anak akan menyebabkan kelebihan berat badan yang menetap dan pada akhirnya menimbulkan berbagai penyakit. Sejumlah penelitian telah membuktikan adanya hubungan yang positif antara kebiasaan makan tidak sehat dengan kejadian kelebihan berat badan pada anak-anak. ${ }^{12,13}$

Selain kebiasaan makan, aktivitas fisik juga sangat mempengaruhi kejadian kelebihan berat badan . Semakin maju teknologi menyebabkan anak memiliki gaya hidup pasif, jarang melakukan aktifitas fisik (sedentary lifestyle), anak lebih memilih menghabiskan waktu di depan televisi, bermain komputer atau video games. ${ }^{14}$ WHO mengeluarkan rekomendasi tentang anjuran melakukan aktivitas fisik sedang sampai berat sekurang - kurangnya 60 menit sehari dalam seminggu. ${ }^{15}$ Penelitian sebelumnya di Manado menyatakan bahwa menonton televisi dan atau bermain video game memiliki kontribusi yang signifikan terhadap kejadian obesitas pada anak jika dilakukan lebih dari 1 jam setiap harinya. ${ }^{16}$
Berdasarkan lokasinya, masalah gizi lebih saat ini tidak hanya terjadi di wilayah perkotaan akan tetapi mulai terjadi juga di perdesaan. Hasil Riskesdas 2007 menunjukkan persentase kelebihan berat badan pada anak di perkotaan (10,6\% laki-laki, $7,1 \%$ perempuan) cenderung lebih tinggi daripada di desa ( $8,8 \%$ laki-laki, $6 \%$ perempuan), namun jika dilihat persentasenya tidak berbeda jauh. Hasil yang serupa juga ditemukan pada penelitian yang dilakukan di beberapa wilayah di Indonesia seperti yang dilakukan di Bali dan Yogyakarta. ${ }^{17,18}$ Hasil penelitian di atas mengindikasikan bahwa masalah kelebihan berat badan terjadi baik di wilayah perkotaan maupun pedesaan.

Wilayah Kecamatan Getasan yang berada di kaki gunung Merbabu merupakan salah satu wilayah pedesaan di Kabupaten Semarang yang berbatasan dengan beberapa kota yaitu Temanggung, Magelang, Boyolali dan Salatiga. Berdasarkan data laporan kesehatan Tahun 2016 dari salah satu puskesmas di Kecamatan tersebut yaitu Puskesmas Getasan, diketahui bahwa angka kejadian obesitas di wilayah kerja tersebut cukup tinggi yaitu $27,18 \%$. Namun demikian data tersebut merupakan data penjaringan penduduk yang berusia 15 tahun ke atas. Data tentang kejadian kelebihan berat badan usia anak sekolah tidak terdapat pada laporan puskesmas tersebut. Berdasarkan pemaparan tersebut tentang permasalahan kelebihan berat badan pada anak-anak maka peneliti ingin mengetahui hubungan antara pola makan dan aktivitas fisik dengan kejadian kelebihan berat badan pada anak Sekolah Dasar usia 10-12 tahun di Kecamatan Getasan.

\section{BAHAN DAN METODE}

Penelitian ini menggunakan desain cross sectional yaitu pengamatan yang dilakukan sekaligus pada satu waktu. Penelitian dilakukan pada bulan Maret 2017 - Mei 2017 pada 13 sekolah dasar di Kecamatan Getasan. Pemilihan sekolah dilakukan secara simple random sampling pada setiap kelurahan yang ada di Kecamatan Getasan. Populasi pada penelitian ini adalah semua murid kelas 4-5 yang berusia $10-12$ tahun di 13 sekolah dasar target pada periode penelitian ini dilakukan. Jumlah sampel yang digunakan adalah 52 anak kelebihan berat badan dan 52 anak berat badan normal. Penentuan jumlah sampel berdasarkan jumlah minimal sampel penelitian korelasi yaitu 30 sampel. $^{18}$

Variabel terikat pada penelitian ini adalah kejadian kelebihan berat badan. Status kelebihan berat badan ditentukan berdasarkan indeks IMT/U yaitu Zscore menurut World Health Organization (WHO) untuk kelompok usia 10-12 tahun. Kriteria inklusi pada penelitian ini adalah siswa sekolah dasar usia 10-12 tahun dengan status gizi lebih yaitu indeks IMT 
terhadap usia (nilai Z-score) $>1$ SD dan normal dengan indeks IMT terhadap usia (nilai Z-score) -2 SD sampai dengan 1 SD. Variabel bebas yaitu pola makan dan aktivitas fisik. Data pola makan diperoleh melalui wawancara dengan menggunakan formulir FFQ (Food Frequency Questionnaire), sedangkan data aktivitas fisik diperoleh dengan menggunakan Physical Activity Questionnaire For Older Children (PAQ-C). Karakteristik responden dikumpulkan melalui wawancara menggunakan kuesioner identitas responden.

Analisis data menggunakan program komputer Microsoft excell dan Statistical Program for Social Science (SPSS). Program SPSS yang digunakan adalah Chi-Square untuk mengetahui hubungan aktivitas fisik dan kejadian kelebihan berat badan, Independent T test untuk mengetahui perbedaan pola konsumsi antara anak berstatus gizi normal dan kelebihan berat badan. Data konsumsi pangan diperoleh dari FFQ (Food Frequency Questionnaire) kemudian dikonversikan menjadi berapa kali perbulan dan diinterpretasikan menjadi tidak pernah, jarang $: \leq 2 \mathrm{x} /$ bulan, kadang : 1-2 kali/minggu, biasa: 3-6 kali/minggu, sering : 1x/hari dan sering sekali : > 1x/hari. ${ }^{19}$ Status gizi ditentukan melalui software WHO Anthroplus yang mengacu pada referensi WHO 2007 (IMT/U).

Sebelum melakukan penelitian, responden yang didampingi orang tua terlebih dahulu diminta untuk membaca dan menandatangani Informed Concent. Informed Concent tersebut berisi bahwa responden dengan sukarela memberi data identitas diri, melakukan pengukuran antropometri dan melakukan wawancara mengenai pola makan responden dan bersedia untuk mengisi dengan jujur dan apa adanya.

\section{HASIL}

Karakteristik siswa yang menjadi responden pada penelitian ini dapat dilihat pada Tabel 1. Siswa yang memiliki status gizi lebih dan status gizi normal masing-masing 52 orang, sehingga total ada 104 responden. Berdasarkan usia, responden terbanyak berusia 11 tahun $(51,92 \%)$. Jumlah responden laki-laki pada kelompok anak kelebihan berat badan lebih banyak yaitu 55,76\% dibandingkan pada kelompok normal $(46,15 \%)$ sebaliknya responden perempuan lebih banyak di kelompok normal $(53,84 \%)$ dibanding kelompok kelebihan berat badan $(44,23 \%)$.

Tabel 1. Karakteristik Responden Penelitian Berdasarkan Usia di Sekolah Dasar Kecamatan Getasan

\begin{tabular}{|c|c|c|c|c|}
\hline \multirow{3}{*}{ Karakteristik } & \multicolumn{4}{|c|}{ Status Gizi } \\
\hline & \multicolumn{2}{|c|}{ Normal } & \multicolumn{2}{|c|}{ Kelebihan Berat Badan } \\
\hline & $\mathbf{n}$ & $\%$ & $\mathbf{n}$ & $\%$ \\
\hline \multicolumn{5}{|l|}{ Usia (tahun) } \\
\hline 10 & 17 & 32,69 & 16 & 30,76 \\
\hline 11 & 27 & 51,92 & 25 & 48 \\
\hline 12 & 8 & 15,38 & 11 & 21,15 \\
\hline \multicolumn{5}{|l|}{ Jenis Kelamin } \\
\hline Laki-laki & 24 & 46,15 & 29 & 55,76 \\
\hline Perempuan & 28 & 53,84 & 23 & 44,23 \\
\hline \multicolumn{5}{|l|}{ Pendidikan terakhir ayah } \\
\hline Tamat SD kebawah & 29 & 56,86 & 13 & 27,65 \\
\hline Tamat SLTP & 13 & 25,49 & 18 & 38,29 \\
\hline Tamat SLTA keatas & 9 & 17,64 & 16 & 34 \\
\hline \multicolumn{5}{|l|}{ Pendidikan terakhir ibu } \\
\hline Tamat SD kebawah & 15 & 31,25 & 18 & 37,5 \\
\hline Tamat SLTP & 23 & 47,91 & 15 & 31,25 \\
\hline Tamat SLTA keatas & 10 & 20,83 & 15 & 31,25 \\
\hline \multicolumn{5}{|l|}{ Pekerjaan Ayah } \\
\hline PNS & 1 & 1,96 & 2 & 4,25 \\
\hline Pegawai Swasta & 5 & 9,8 & 10 & 21,27 \\
\hline Wiraswasta & 5 & 9,8 & 13 & 27,65 \\
\hline Petani & 13 & 25,49 & 11 & 23,4 \\
\hline Buruh & 26 & 50,98 & 9 & 19,14 \\
\hline Tidak bekerja & 1 & 1,96 & 2 & 4,25 \\
\hline \multicolumn{5}{|l|}{ Pekerjaan Ibu } \\
\hline PNS & 2 & 4,16 & 5 & 10,41 \\
\hline Pegawai Swasta & 1 & 2 & 4 & 8,33 \\
\hline Wiraswasta & 7 & 14,58 & 9 & 18,75 \\
\hline Petani & 9 & 18,75 & 9 & 18,75 \\
\hline Buruh & 21 & 43,75 & 8 & 16,67 \\
\hline Tidak bekerja & 8 & 16,67 & 13 & 27 \\
\hline
\end{tabular}

Keterangan : 14 Orang tua siswa dari jumlah keseluruhan sudah meninggal (ayah 6 dan ibu 8). 
Tabel 2. Hubungan IMT Orang Tua dengan Kejadian Kelebihan Berat Badan

\begin{tabular}{|c|c|c|c|c|c|}
\hline & \multicolumn{4}{|c|}{ Status Gizi } & \multirow{3}{*}{$p^{*}$} \\
\hline & \multicolumn{2}{|c|}{ Normal } & \multicolumn{2}{|c|}{ Kelebihan Berat Badan } & \\
\hline & $\mathbf{n}$ & $\%$ & $\mathbf{n}$ & $\%$ & \\
\hline \multicolumn{6}{|l|}{ IMT Ayah } \\
\hline Kurus & 1 & 2,12 & 1 & 2,17 & \multirow{3}{*}{0,271} \\
\hline Normal & 39 & 82,97 & 34 & 73,91 & \\
\hline Preobes + Obesitas & 7 & 14,89 & 11 & 23,91 & \\
\hline \multicolumn{6}{|l|}{ IMT Ibu } \\
\hline Kurus & 2 & 4,17 & 1 & 2,17 & \multirow{3}{*}{0,04} \\
\hline Normal & 28 & 58,33 & 18 & 39,13 & \\
\hline Preobes + Obesitas & 18 & 37,5 & 27 & 58,69 & \\
\hline
\end{tabular}

${ }^{*}$ Uji Chi-square

Keterangan : 14 0rang tua siswa dari jumlah keseluruhan sudah meninggal (ayah 6 dan ibu 8).

Tabel 3. Hubungan Asupan Makan dengan Kejadian Kelebihan Berat Badan Berdasarkan IMT/U (Z-score)

\begin{tabular}{|c|c|c|c|c|c|c|c|}
\hline & \multicolumn{6}{|c|}{ Status Gizi } & \multirow{3}{*}{$p^{*}$} \\
\hline & \multicolumn{3}{|c|}{ Normal } & \multicolumn{3}{|c|}{ Kelebihan Berat Badan } & \\
\hline & $\mathbf{n}$ & $\%$ & Rerata \pm SD & $\mathbf{n}$ & $\%$ & Rerata \pm SD & \\
\hline Karbohidrat (kali/hari) & & & $3,85 \pm 0,9$ & & & $4,76 \pm 1,5$ & 0,001 \\
\hline Sering sekali & 52 & 100 & & 52 & 100 & & \\
\hline Lauk hewani (kali/hari) & & & $2,11 \pm 0,84$ & & & $4,26 \pm 1,58$ & 0,001 \\
\hline Biasa & 3 & 5,8 & & 1 & 1,92 & & \\
\hline Sering & 20 & 38,4 & & 0 & 0 & & \\
\hline Sering sekali & 29 & 55,7 & & 51 & 98 & & \\
\hline Lauk nabati (kali/hari) & & & $1,60 \pm 0,97$ & & & $0,99 \pm 0,53$ & 0,001 \\
\hline Jarang & 0 & 0 & & 1 & 1,92 & & \\
\hline Kadang & 2 & 3,84 & & 7 & 13,46 & & \\
\hline Biasa & 8 & 15,38 & & 14 & 26,92 & & \\
\hline Sering & 33 & 63,46 & & 29 & 55,76 & & \\
\hline Sering sekali & 9 & 17,3 & & 1 & 1,92 & & \\
\hline Sayur (kali/hari) & & & $3 \pm 1,04$ & & & $1,83 \pm 0,79$ & 0,001 \\
\hline Tidak pernah & 2 & 3,84 & & 1 & 1,92 & & \\
\hline Biasa & 2 & 3,84 & & 3 & 5,8 & & \\
\hline Sering & 1 & 1,92 & & 27 & 51,9 & & \\
\hline Sering sekali & 47 & 90,38 & & 21 & 40,38 & & \\
\hline Buah (kali/hari) & & & $0,69 \pm 0,41$ & & & $0,57 \pm 0,30$ & 0,115 \\
\hline Tidak pernah & 1 & 1,92 & & 0 & 0 & & \\
\hline Jarang & 0 & 0 & & 0 & 0 & & \\
\hline Kadang & 14 & 26,92 & & 14 & 26,92 & & \\
\hline Biasa & 23 & 44,23 & & 32 & 61,53 & & \\
\hline Sering & 14 & 26,92 & & 6 & 11,53 & & \\
\hline Sering sekali & 0 & 0 & & 0 & 0 & & \\
\hline Jajanan (kali/hari) & & & $3,87 \pm 1,5$ & & & $4,14 \pm 1,53$ & 0,369 \\
\hline Sering & 2 & 3,84 & & 3 & 5,76 & & \\
\hline Sering sekali & 50 & 96,15 & & 49 & 94,23 & & \\
\hline
\end{tabular}

*Uji Independent T-test

Berdasarkan pendidikan orang tua, kelompok anak kelebihan berat badan paling banyak memiliki ayah tamat SLTP yaitu 38,29\%. Adapun pendidikan orang tua kelompok anak dengan status gizi normal paling banyak memiliki ayah tamat SD ke bawah $(56,86 \%)$. Berbeda dengan latar belakang pendidikan ayah, sebagian besar anak dengan kelebihan berat badan mempunyai ibu berpendidikan tamat SD ke bawah yaitu $37,5 \%$.

Sebagian besar pekerjaan ayah pada kelompok anak berstatus gizi normal sebagai buruh yaitu 50,98\% sedangkan pada kelompok anak kelebihan berat badan sebagai wiraswasta $27,65 \%$. Sedangkan jenis pekerjaan ibu pada anak kelebihan berat badan adalah tidak bekerja $(27 \%)$.

Salah satu faktor risiko terjadinya kelebihan berat badan termasuk obesitas adalah adanya faktor keturunan. Hasil analisis dengan uji Chi-Square pada Tabel 2 menunjukkan tidak ada hubungan antara kejadian kelebihan berat badan anak dengan IMT atau status gizi ayah $(\mathrm{p}=0,271)$. Namun diketahui bahwa ada hubungan antara kelebihan berat badan anak dengan 
IMT/status gizi ibu ( $\mathrm{p}=0,040)$. Sebesar 58,69\% ibu dengan status gizi preobes dan obesitas memiliki anak yang kelebihan berat badan .

Hasil analisis statistika menggunakan independent T-test pada Tabel 3 menunjukkan bahwa kebiasaan konsumsi karbohidrat, lauk hewani, lauk nabati dan konsumsi sayur berbeda secara bermakna antara anak dengan status gizi normal dan kelebihan berat badan. Sedangkan tidak ada perbedaan konsumsi buah dan jajanan pada kedua kelompok. Rerata konsumsi karbohidrat $(4,76 \pm 1,5)$ dan lauk hewani $(4,26 \pm 1,58)$ pada anak dengan kelebihan berat badan lebih tinggi dibandingkan anak dengan status gizi normal. Sebaliknya rerata lauk nabati $(0,99 \pm 0,53)$ dan sayur $(1,83 \pm 0,79)$ pada anak dengan kelebihan berat badan lebih rendah dibandingkan anak dengan status gizi normal.
Frekuensi asupan makanan siswa yang menjadi responden penelitian ini dapat dilihat pada Tabel 3. Seluruh responden mempunyai kebiasaan konsumsi karbohidrat dalam kategori sering sekali (100\%). Kebiasaan konsumsi lauk hewani kategori sering sekali pada kelompok anak kelebihan berat badan lebih tinggi (98\%) dibandingkan anak yang berstatus gizi normal $(55,7 \%)$. Kebiasaan konsumsi lauk nabati kategori sering sekali pada kelompok anak berstatus gizi normal lebih tinggi $(17,3 \%)$ dibandingkan anak kelebihan berat badan $(1,92 \%)$. Kebiasaan konsumsi sayur kategori sering sekali pada anak berstatus gizi normal lebih tinggi (90,38\%) dibandingkan anak yang kelebihan berat badan $(40,38 \%)$. Frekuensi makan buah dan jajanan tidak terlalu banyak perbedaan pada anak yang memiliki kelebihan berat badan dan anak yang berstatus gizi normal.

Tabel 4. Hubungan Aktivitas Fisik dengan Kejadian Kelebihan Berat Badan

\begin{tabular}{lccccc}
\hline & \multicolumn{3}{c}{ Status Gizi } \\
\cline { 2 - 5 } & $\mathbf{n}$ & Normal & \multicolumn{2}{c}{ Kelebihan Berat Badan } & $\boldsymbol{p}^{*}$ \\
\cline { 2 - 5 } & & $\%$ & $\mathbf{n}$ & 0,003 \\
Aktifitas Fisik & 11 & 21,15 & 24 & 46,15 \\
Ringan & 33 & 63,46 & 27 & 51,92 \\
Sedang & 8 & 15,38 & 1 & 1,92 \\
Berat & & &
\end{tabular}

* Uji Chi-Square

Keterangan : Ringan : 1-2 kali/minggu; Sedang : 3-4 kali/minggu; Berat : 5-6 kali/minggu

Berdasarakan hasil uji analisis Chi-Square yang disajikan di Tabel 4, ada hubungan yang bermakna antara aktivitas fisik dengan kejadian kelebihan berat badan $(\mathrm{p}=0.003)$. Anak yang memiliki berat badan normal lebih banyak melakukan aktivitas fisik berat $(15,38 \%)$ dibandingkan anak yang memiliki berat badan lebih $(1,92 \%)$. Aktivitas fisik ringan lebih banyak dilakukan pada anak kelebihan berat badan $(46,15 \%)$ dibandingkan anak dengan berat badan normal $(21,15 \%)$.

\section{PEMBAHASAN}

\section{Karakteristik Responden}

Tabel 1 menunjukkan bahwa kasus kelebihan berat badan banyak terjadi pada siswa berjenis kelamin laki-laki. Hubungan antara kejadian kelebihan berat badan dengan jenis kelamin pada usia anak-anak memberikan hasil yang tidak selalu sama. Beberapa penelitian menunjukkan hasil bahwa kasus kelebihan berat badan lebih banyak pada anak laki-laki ${ }^{20,21}$ sedangkan penelitian lain menunjukkan hasil bahwa kelebihan berat badan lebih banyak pada anak perempuan. $^{22}$

Pendidikan terakhir orang tua khususnya ayah, diduga berhubungan dengan tingkat status ekonomi keluarga. Semakin tinggi pendidikan seseorang maka semakin besar peluang memperoleh pekerjaan yang baik sehingga semakin tinggi pendapatan ekonomi keluarganya. Pada Tabel 1 anak yang kelebihan berat badan sebagian besar pendidikan terakhir ayahnya tamat SLTP atau lebih tinggi. Pendapatan ekonomi yang tinggi akan memberi anak kemudahan untuk memperoleh makanan yang tinggi energi dan lemak. ${ }^{23}$ Selain latar belakang pendidikan dan pekerjaan ayah, latar belakang pendidikan dan pekerjaan ibu juga penting dalam kejadian kelebihan berat badan dan kebiasaan makan anak. Pendidikan ibu yang baik akan lebih mudah untuk menerima informasi dari luar terutama tentang cara pengasuhan anak yang baik dan bagaimana menjaga kesehatan anak. ${ }^{23}$ Pada Tabel 1 anak kelebihan berat badan memiliki ibu dengan pendidikan terakhir tamat SD kebawah sedangkan anak yang berstatus gizi normal sebagian besar pendidikan terakhir ibu tamat SLTP. Tingkat pengetahuan yang kurang memungkinkan mereka kurang dapat memilih menu makanan yang bergizi. Sebagian kejadian kelebihan berat badan dapat dihindari apabila mempunyai ilmu pengetahuan yang cukup tentang makanan bergizi dan pengaturan pola makan. ${ }^{24}$ 


\section{Hubungan IMT Orang Tua dengan Kejadian Kelebihan Berat Badan}

Obesitas adalah keadaan akumulasi lemak dalam tubuh yang abnormal atau berlebihan yang dapat mengganggu kesehatan. ${ }^{25}$ Sejumlah penelitian menunjukkan bahwa genetik merupakan salah satu faktor risiko terjadinya obesitas. Anak yang memiliki orang tua obesitas akan beresiko mengalami obesitas. Apabila kedua orang tua obesitas kemungkinan anak menjadi obesitas sebesar $80 \%$, apabila salah satu orang tua obesitas kejadian obesitas pada anak menjadi $40 \%$ dan bila kedua orang tua tidak obesitas prevalensi anak menjadi obesitas sebesar 14\%. ${ }^{26,27}$ Uji chi-square pada Tabel 2 menunjukkan tidak ada hubungan antara kejadian kelebihan berat badan anak dengan IMT ayah, tetapi ada hubungan bermakna dengan IMT ibu.

Selain adanya faktor genetik yang diturunkan oleh orangtua kepada anaknya, kebiasaan pola makan dan gaya hidup orang tua yang tidak baik juga dapat mempengaruhi kejadian kelebihan berat badan pada anak. Seorang anak yang orang tuanya gemuk dan terbiasa mengonsumsi makan makanan berkalori tinggi dan tidak aktif beraktivitas, memiliki kemungkinan besar anak tersebut akan mewarisi kebiasaan yang sama dan menjadikan anak memiliki berat badan yang berlebih. ${ }^{28}$

\section{Hubungan Asupan Makanan dengan Kejadian Kelebihan Berat Badan}

Obesitas atau kelebihan berat badan dapat terjadi karena adanya ketidakseimbangan antara asupan energi dan keluaran energi. Jika energi yang masuk melalui asupan makanan melebihi kebutuhan dan tidak diimbangi oleh banyaknya energi yang dikeluarkan, maka kelebihan energi disimpan dalam bentuk lemak tubuh yang menyebabkan kelebihan berat badan atau obesitas. Pola makan yang tidak sehat seperti makan berlebihan, tinggi energi dan tinggi lemak merupakan salah satu faktor risiko kelebihan berat badan atau obesitas.

Hasil uji statistik konsumsi sumber karbohidrat pada Tabel 3 menunjukkan ada perbedaan bermakna pada anak kelebihan berat badan dan normal. Berdasarkan analisis data lebih lanjut, sebagian anak kelebihan berat badan mengonsumsi sumber karbohidrat lebih sering jika dibandingkan dengan anak yang berstatus gizi normal yaitu lebih dari 3 kali perhari. Konsumsi karbohidrat dapat mempengaruhi status gizi seseorang. Karbohidrat yang berlebihan dalam tubuh akan disimpan dalam bentuk glikogen dalam jaringan otot tubuh dan dalam bentuk lemak dalam jaringan adiposa, sehingga dapat menimbulkan kelebihan berat badan atau obesitas.

Perbedaan bermakna konsumsi lauk hewani dan lauk nabati terjadi antara anak kelebihan berat badan dan normal. Kelompok kelebihan berat badan lebih banyak yang sering sekali mengonsumsi lauk hewani (98\%) dibandingkan mengonsumsi lauk nabati $(1,9 \%)$. Sebaliknya, kelompok anak yang berstatus gizi normal banyak yang sering mengonsumsi lauk nabati $(63,46 \%)$ dibandingkan mengonsumsi lauk hewani $(38,4 \%)$. Hasil penelitian yang dilakukan Suryaputra dan Nadhiroh Tahun 2012 menyatakan hal yang sama yaitu ada perbedaan yang bermakna pada konsumsi protein dan lemak antara kelompok obesitas dan non obesitas. ${ }^{29}$ Lauk nabati merupakan sumber protein yang kandungan lemaknya lebih rendah, namun kandungan seratnya tinggi. Protein pada lauk hewani mengandung asam amino yang lebih lengkap, namun memiliki kandungan kolesterol dan lemak jenuh yang lebih tinggi. Konsumsi protein hewani meskipun dibutuhkan oleh tubuh namun konsumsinya harus dibatasi. Konsumsi protein hewani yang berlebihan dapat memicu timbulnya berbagai penyakit dan kelebihan berat badan. Beberapa penelitian menunjukkan bahwa ada hubungan yang signifikan antara asupan protein hewani dan nabati dengan kejadian obesitas..$^{30,31}$

Berdasarkan hasil wawancara yang dilakukan pada penelitian ini, penyebab anak kelebihan berat badan lebih sering mengonsumsi lauk hewani selain dikarenakan pekerjaan orang tua yang cenderung lebih baik, juga dikarenakan lingkungan tempat tinggalnya. Tempat tinggal anak yang kelebihan berat badan lebih dekat dengan pasar dan pusat keramaian sedangkan lingkungan tempat tinggal anak dengan status gizi normal jauh dari jalan utama, sulit untuk mengakses lauk hewani sehingga orang tua lebih sering menyediakan lauk nabati yang lebih mudah ditemui di lingkungan rumahnya.

Konsumsi sayur dan buah sangat penting dalam kehidupan sehari-hari karena berfungsi sebagai zat pengatur, mengandung vitamin dan mineral, memiliki kadar air tinggi dan sumber serat makanan. ${ }^{32,33}$ Apabila terjadi kekurangan dalam konsumsi sayur dan buah, akan menyebabkan tubuh kekurangan gizi seperti vitamin, mineral, serat dan tidak seimbangnya asam basa tubuh, sehingga dapat menimbulkan berbagai macam penyakit degeneratif seperti obesitas. ${ }^{34}$ WHO (2003) merekomendasikan kecukupan konsumsi sayur dan buah 500 gram perhari atau sebanyak 3-4 porsi sehari. ${ }^{35}$ Selain itu, anjuran konsumsi buah dan sayur menurut pedoman gizi seimbang adalah 2-3 porsi/hari untuk buah dan 3-4 porsi/hari untuk sayur. ${ }^{36}$

Uji statistik yang telah dilakukan pada Tabel 3 menunjukkan hasil bahwa ada perbedaan bermakna pada konsumsi sayur antara anak berat normal dan kelebihan berat badan. Hasil tersebut menunjukan bahwa semakin berlebih status gizi anak, konsumsi sayur akan semakin sedikit. Persentase konsumsi sayur anak yang berstatus gizi normal lebih tinggi jika dibandingkan dengan anak kelebihan berat badan. Hampir semua anak yang memiliki status gizi normal 
mengonsumsi sayur lebih dari 1 kali perhari. Banyak alasan yang menyebabkan anak yang berstatus gizi normal lebih sering mengonsumsi sayur, salah satunya karena sebagian besar mata pencarian orang tua anak berstatus gizi normal adalah petani sayur sehingga akses untuk memperoleh sayur sangat mudah, bahkan tidak perlu untuk membeli. Anak kelebihan berat badan lebih suka mengonsumsi jenis makanan yang berlemak seperti ayam, ikan, daging dan sosis. Berdasarkan wawancara mereka menyatakan kurang suka mengonsumsi sayur dan mengaku bahwa orang tuanya jarang memasak sayur.

Berbeda dengan sayur, uji statistik pada konsumsi buah menunjukkan bahwa tidak ada perbedaan bermakna pada kedua kelompok tersebut. Anak yang berstatus gizi normal maupun kelebihan berat badan rata-rata konsumsi yang tidak jauh berbeda. Berdasarkan data, baik kelompok anak dengan berat badan normal ataupun lebih mengonsumsi buah di bawah rekomendasi WHO, yaitu kurang dari 500 gram perhari atau kurang dari 3-4 porsi sehari.

Suatu penelitian menyatakan bahwa ada perbedaan bermakna pada kebiasaan mengonsumsi serat (sayur dan buah) antara anak obesitas dan non obesitas. Anak obesitas mengonsumsi lebih sedikit makanan yang mengandung serat dibandingkan anak non-obesitas. ${ }^{37}$ Penelitian di Inggris mengungkapkan bahwa kurangnya konsumsi serat makanan berhubungan dengan kegemukan yang lebih tinggi pada anak-anak. ${ }^{38}$

Hasil uji statistik pada Tabel 3 membuktikan tidak ada perbedaan bermakna antara kebiasaan jajan/mengonsumsi cemilan antara siswa berat badan normal dan kelebihan berat badan. Frekuensi mengonsumsi jajanan anak yang memiliki status gizi normal dan kelebihan berat badan hampir sama yaitu (96,15\% dan 94,23\%). Walaupun tidak ada perbedaan bermakna pada konsumsi jajanan pola konsumsi makanan jajanan harus dikontrol. Jika anak mengonsumsi lemak yang tinggi, mengandung bahan pengawet, tinggi gula dan tinggi garam secara terus menerus tanpa adanya olahraga dan konsumsi serat, maka akan berdampak pada kelebihan berat badan. Penelitian yang dilakukan di Makassar dan Yogyakarta yang menyatakan tidak ada hubungan yang signifikan antara konsumsi jajanan dengan kejadian kelebihan berat badan..$^{39,40}$

\section{Hubungan Aktivitas Fisik dengan Kejadian Kelebihan Berat Badan}

Berdasarkan hasil uji statistika chi-square pada Tabel 4 diketahui bahwa ada hubungan bermakna antara aktivitas fisik dengan kejadian kelebihan berat badan. Uji statistik tersebut menunjukkan bahwa semakin anak memiliki berat badan yang berlebih aktivitas fisiknya akan semakin ringan. Dari Tabel 4 dapat dilihat bahwa anak berstatus gizi berat badan berlebih memiliki aktivitas fisik sedang sampai ringan, sedangkan pada anak yang berstatus gizi normal memiliki aktivitas fisik sedang dan ada beberapa anak yang memiliki aktivitas fisik berat. Anak yang kurang aktif membutuhkan kalori dalam jumlah sedikit dibandingkan dengan anak dengan aktivitas tinggi. Anak yang tidak melakukan aktivitas fisik seimbang dan mengonsumsi makanan yang tinggi lemak akan cenderung mengalami obesitas. Aktivitas fisik diperlukan untuk membakar energi dalam tubuh. Apabila energi yang masuk di dalam tubuh berlebih dan tidak diimbangi dengan aktivitas fisik yang seimbang akan meningkatkan kejadian kelebihan berat badan pada anak. ${ }^{27}$ Penelitian ini sejalan dengan penelitian yang dilakukan Zamzani dkk yang meunjukkan bahwa ada hubungan antara aktivitas fisik dengan kejadian obesitas pada anak yang melakukan aktivitas sedang-berat $<1 \mathrm{jam} / \mathrm{hari}$ berpeluang $5 \mathrm{kali}$ lebih besar untuk mengalami obesitas daripada anak dengan aktivitas sedang-berat $>1$ jam/hari. ${ }^{41}$ Penelitian yang dilakukan Kelishadi dkk pada Tahun 2007 menyatakan bahwa ada hubungan yang bermakna antara lama waktu yang digunakan untuk melakukan aktivitas fisik dan pengeluaran energi dengan kejadian kelebihan berat badan. ${ }^{42}$

Perbedaan aktivitas anak dengan berat badan normal dan anak yang mengalami kelebihan berat badan di Kecamatan Getasan berbeda secara signifikan. Ketika jam istirahat di sekolah anak kelebihan berat badan lebih memilih untuk duduk diam di kelas maupun membaca buku, anak yang berstatus gizi normal lebih cenderung menyukai bermain di luar. Anak yang memiliki kelebihan berat badan ketika pulang sekolah lebih banyak menghabiskan waktu untuk menonton televisi, kursus atau les dan tidur siang, sedangkan anak yang memiliki status gizi normal lebih cenderung memilih untuk bermain di luar rumah seperti bermain voly, sepakbola dan berlari setelah pulang sekolah. Selain itu, anak yang memiliki status gizi normal cenderung berjalan kaki ketika berangkat dan pulang sekolah sedangkan anak yang kelebihan berat badan sebagian besar pergi ke sekolah dengan membawa kendaraan sendiri maupun diantar orang tua dengan menggunakan kendaraan bermotor.

\section{SIMPULAN}

Aktivitas fisik berhubungan dengan kejadian kelebihan berat badan pada anak sekolah dasar. Pola makan (karbohidrat, lauk hewani, lauk nabati dan sayur) pada anak berat badan normal dan kelebihan berat badan berbeda nyata. Sebaliknya, buah dan jajanan tidak memiliki perbedaan secara nyata. 
Saran untuk institusi sekolah memberikan pilihan kegiatan ekstrakulikuler yang beragam agar siswa tertarik untuk mengikuti kegiatan di sekolah serta mengoptimalkan jam olahraga sehingga dapat menurunkan risiko terjadinya kelebihan berat badan. Saran untuk keluarga sebaiknya orang tua mengawasi kebiasaan makan anak yaitu dengan membatasi konsumsi makanan yang tinggi kalori dan mendorong anak untuk mengonsumsi makanan tinggi serat. Orang tua juga perlu mengajarkan anak untuk hidup sehat dengan mengajak anak melakukan aktivitas fisik atau berolahraga.

\section{DAFTAR PUSTAKA}

1. Cali AMG, Caprio S. Obesity in children and adolescents. J Clin Endocrinol Metab [Internet]. 2008;93(11_supplement_1):s31-6. Available from: https://academic.oup.com/jcem/articlelookup/doi/10.1210/jc.2008-1363

2. Rachmi CN, Li M, Alison Baur L. Overweight and obesity in Indonesia: prevalence and risk factorsa literature review. Public Health. 2017;147:20-9.

3. Low LCK. Childhood obesity in developing countries. World J Pediatr. 2010;6(3):197-8.

4. Badan Penelitian Dan Pengembangan Departemen Kesahatan RI. Riset Kesehatan Dasar (RISKESDAS 2007). Ris Kes Das; 2013.384.

5. Badan Penelitian Dan Pengembangan Departemen Kesehatan RI. Riset Kesehatan Dasar (RISKESDAS 2010) Ris Kes Das; 2010.1-111.

6. Badan Penelitian Dan Pengembangan Departemen Kesehatan RI. Riset Kesehatan Dasar (RISKESDAS 2013) Ris Kes Das; 2013.1-384.

7. Simmond M. et.al., Predicting adult obesity from children obesity: a systematic review and metaanalysis. White Rose Research Online. University of York. 2015.

8. Lumoindong A, Umboh A, Masloman $\mathrm{N}$. Hubungan obesitas dengan profil tekanan darah pada anak usia 10-12 tahun di kota Manado 1. J eBiomedik. 2013;1(1):147-53.

9. Sartika RAD. Faktor risiko obesitas pada anak 515 tahun di Indonesia. Makara, Kesehatan. 2011;15(1):37-43.

10. Behan DF, Cox SH. Obesity and its relation to mortality and morbidity costs. Soc Actuar. 2010;(December):1-77.

11. Reilly JJ, Kelly J. Long-term impact of overweight and obesity in childhood and adolescence on morbidity and premature mortality in adulthood: systematic review. Int $\mathbf{J}$ Obes [Internet]. 2011;35(7):891-8. Available from: http://www.nature.com/doifinder/10.1038/ijo.201 0.222

12. Payab M, et.al. Association of junk food consumption with high blood pressure and obesity in Iranian children and adolescents: the CASPIAN-IV study. J Pediatr (Rio J). 2015; 91(2):196-205

13. Huang JY, Qi SJ. Childhood obesity and food intake. World Journal of Pediatric. 2015; 11(2): 101-107.

14. Kurdaningsih SV, Sudargo T, Lusmilasari L. Physical activities and sedentary lifestyle towards teenagers overweight/obesity status. International Journal of Community Medicine and Public Health. 2016; 3(3):630-635.

15. WHO. Global recommendations on physical activity for health; 2010 .

16. Tando M HT. No Title. Aktivitas fisik dan pola makan dengan obesitas sentral pada tokoh agama di kota Manado. GIZIDO. 2012;4:289-98.

17. Badan Penelitian dan Pengembangan Departemen Kesehatan RI. Riset Kesehatan Dasar ( Riskesdas ) Provinsi Bali Tahun 2007. 2009;1-246.

18. Nurwanti E, Hadi H, Julia M. Paparan iklan junk food dan pola konsumsi junk food sebagai faktor risiko terjadinya obesitas pada anak sekolah dasar kota dan desa di Daerah Istimewa Yogyakarta. Jurnal Gizi Klinik Indonesia. 2013; 1(2): 59-70

19. Gibson R. Principal of nutrition assesment. Oxford Univ Press; 2005.

20. Danari AL, Mayulu N, Onibala F. Hubungan aktivitas fisik dengan kejadian obesitas pada anak sd di kota Manado. ejournal keperawatan (e-Kp). 2013;1(1):4-7.

21. Ogden CL, Carrol MD, Kit BK FK. Prevalence of childhood and adult obesity in the United State 2011-2012. J Am Med Assoc. 2014;311(8):80614.

22. Hendro B, Sefti R M. Hubungan pola makan dengan kejadian obesitas pada anak usia 8-10 tahun di SD Katolik 03 Frater Don Bosco Manado. J Hub Pola Makan Dengan Kejadian Obesitasa Pada Anak. 2014;2(173):1-7.

23. Putra WN. Hubungan pola makan, aktivitas fizik dan aktivitas sendetari dengan overweight di SMAN 5 Surabaya. Jurnal Berkala Epidemiologi. 2017; 5(3):298-310

24. Poskitt E EL. Management childhood obesity. Cambridge Univ Press; 2008.

25. Badan Penelitian dan Pengembangan Kesehatan Departemen Kesehatan RI. Laporan Riset Kesehatan Dasar Provinsi Jawa Timur. 2007;

26. Juliantini NPL, Sidiartha IGL. Hubungan Riwayat Obesitas Pada Orangtua Dengan Kejadian Obesitas Pada Anak Sekolah Dasar. 2014;(Cdc):1-13.

27. Kurdanti W, Suryani I, Syamsiatun NH, Siwi LP, Adityanti MM, Mustikaningsih D, et al. Faktorfaktor yang mempengaruhi kejadian obesitas pada 
remaja. J Gizi Klin Indones. 2015;11(4):179-90.

28. Rina N. Pencegahan dan Manajemen Obesitas. Elex Media Komputindo. 2011;

29. Suryaputra K. dan Nadiroh SR. Perbedaan Pola Makan dan Aktivitas Fisik antara Remaja Obesitas dan Non Obesitas. Makara, Kesehatan 2012; 6 (1): 45-50.

30. Beti D N W. Hubungan Asupan Protein Dengan Obesitas Pada Remaja. Program Studi Gizi, Ilmu Kedokteran, Fak Diponegoro, Univ. 2015;m:4928.

31. Lin Y, Mouratidou T, Vereecken C, Kersting M, Bolca S, de Moraes ACF, et al. Dietary animal and plant protein intakes and their associations with obesity and cardio-metabolic indicators in European adolescents: the HELENA crosssectional study. Nutr J [Internet]. 2015;14(1):10. Available from: http://nutritionj.biomedcentral.com/articles/10.11 86/1475-2891-14-10

32. Vereecken C, Huybrechts I, van HH, Martens V, Wittebroodt I, Maes L: Results from a dietary intervention study in preschools "Beastly Healthy at School. Int J Public Health 2009, 54:142-149. 2.

33. Huybrechts I, Matthys C, Vereecken C, Maes L, Temme EH, Van OH, De BG, De HS: Food intakes by preschool children in flanders compared with dietary guidelines. Int J Environ Res Public Health 2008, 5:243-257.

34. T Swara. Terapi jus buah dan sayur. Puspa Swara. 2008;90.
35. WHO. Fruits and vegetables intake in a sample of 11-year-old children In 9 Europian countries: the pro children cross- sectional survey. Ann Nutr Metab. 2003;236-45.

36. Indonesian Ministry of Health. Nutritional guidelines. 2014;

37. Garipağaoğlu, Muazzez et al. Food types in the diet and the nutrient intake of obese and non-obese children. J Clin Res Ped Endo. 2008;1(2):21-29

38. Johnson, Laura et al. Energy-dense, low-fiber, high-fat dietary pattern is associated with increased fatness in childhood. Am J Clin Nutr. 2008;87:846-54.

39. Anggraeni A. Hubungan pola konsumsi makanan jajanan dengan status gizi dan kadar kolesterol pada anak Sekolah Dasar Negeri IKIP 1 Makassar [Skripsi]. Univ Islam Negeri Alauddin; 2014.

40. Noviani, Kurnia., Afifah, Effatul., Astiti D. Kebiasaan jajan dan pola makan serta hubungannya dengan status gizi anak usia sekolah di SD Sonosewu Bantul Yogyakarta. Gizi dan Diet Indones. 2016;4(2):97-104.

41. Zamzani et al. Aktivitas Fisik berhubungan dengan kejadian obesitas pada anak sekolah dasar. J Gizi dan Diet Indones. 2016;

42. Kelishadi, Roya et al. Association of physical activity and dietary behaviours in relation to the body mass index in a national sampel of Iranian children and adolescents: CASPIAN study. Bull World Health Organ. 2012;85:1-84. 